\title{
Practical indicators for road infrastructure resilience to flood risks in France, case study of Nantes Ring Road network
}

\author{
Zhuyu Yang ${ }^{1, a}$, Katia Laffréchine ${ }^{1}$, Aurélia Bony-Dandrieux² ${ }^{2}$,élène Dolidon ${ }^{3}$ and Bruno Barroca ${ }^{1}$ \\ ${ }^{1}$ Lab’urba, Université Gustave Eiffel, Marne-la-Vallée, France \\ ${ }^{2}$ Laboratoire des Sciences des Risques, IMT Mines Ales, 6 Avenue de Clavières, 30100 Alès, France \\ ${ }^{3}$ Cerema, MAN, 9 Rue René Viviani, 44200 Nantes, France
}

\begin{abstract}
After the adoption of the European Floods Directive in 2007, Preliminary Flood Risk Assessment (EPRI) was carried out in 2011 in France. It highlighted the protection of road infrastructures from flood hazards as an important part of the flood risks management. Assessing infrastructures' resilience by indicators helps urban stakeholders to better understand infrastructures facing flood risks. In order to achieve that, many French public and private institutions discuss relevant assessment indicators in wide varieties of documents, which can be defined as operational indicators. Some of these operational indicators are applied in practical local management, which we call practical indicators. This paper will present an approach to identify French practical and operational indicators of road infrastructures resilience to flood risks. We will also demonstrate how operational indictors can usefully serve as practical indicators in using Nantes Ring Road (NRR) network as the case study. Moreover, French multi-scales involved institutions (like national, regional, departmental and local) will be discussed to describe the national management structure.
\end{abstract}

\section{Introduction}

Increasing number of infrastructures, including the transport systems, water supply networks, buildings, etc., has been following all human activities development, especially urbanization in recent centuries. The concreting of natural areas required for the building of infrastructures and the cities development is, amongst others, one main reason of urban flood. The fact that urban infrastructure needs to be protected from urban flooding may seem paradoxical, given urban flood risk probably from reinforced concrete in over-artificial areas. We can better ensure the well-being of people with a think differently, that urban infrastructure and flooding can co-exist. For new urban areas and areas undergoing urban renewal, like Hamburg Hafencity in Germany, we could built new flood protection systems to guarantees the escape of the people out of the flooded area in in case of emergency (Goltermann1 et al., 2009). However, the majority cities in our world are those that were constructed without a thinking about consequences of the frequency and severity of extreme climate, and those that have difficulty in reconstruction. With this context, as well as global climate change, city's adaptive capacity, facing disasters, has become a key issue and has brought another notion, that of urban resilience.
Road Infrastructures (RIs), considered as one of the critical infrastructures, play an important role, among other things, for a city's economic competitiveness, quality of human life (Pregnolato et al., 2017), and evacuation during catastrophes. RIs' malfunction can disrupt, directly or indirectly, urban basic activities (economies, politics, ecologic, etc.), thus decreasing cities' performance. However, the urban transport system is vulnerable to special events and natural disasters, especially flood hazards. Due to the particularly heavy damages of flooding on traffic, CGDD (2018) explains that road traffic disruptions is one of the main points for assessing flood risk in France. In front of predictable and unpredictable flood hazards, a resilient road network can resist and absorb floods, maintain and restore rapidly functions, learn and improve capacity to cope with future floods, and manage multiple-equilibrium with other urban systems (socio-economic, ecologic, politic, etc.).

Resilience assessment is a popular and common method, which helps us to understand a complex system's resilience, as well as its properties and characteristics. The framework built for resilience assessment is frequently based on indicators, relying on databases that to calculate precisely indicators' value. Resilience assessment reflects particularly interesting properties in risk and disaster prevention. Meanwhile, assessing indicators of flood risks partly contributes to flood management and prevention. 
In France, one-third of municipalities have flood risks in the territory. Flood Risk Prevention Plan (PPRI), published in 1987 and which led France to focus on prevention remains very important for flood risk management (Priest et al., 2016). During the decades of development of flood management in France, many public and private institutions discuss relevant assessment indicators in wide varieties of documents. These indicators can be defined as operational indicators and serve as practical indicators applied in future projects or programmes. Operational indicators refer to indicators suggested by managers in strategies, plans and guides while practical indicators are those used by decision makers in practical flood or urban infrastructure management. This would means that practical indicators are one special type of operational indictor, which are applied on practical local projects. This paper will present 1) how to identify French practical and operational indicators of road infrastructures resilience to flood risks, and 2) how useful operational indicators can be applied as practical indicators through the case study of Nantes Ring Road (NRR).

After the definition of the system of interest (section 2), the section 3 will describe NRR network and the practical indicators used for NRR. Then, in order to find out some operational indicators that can be used for NRR, we will focus on a synthesis of the main French actors (section 4) and documents (section 5) involved in floods management and road infrastructure management. It allows us to select some operational indicators and discuss their application on NRR network in section 6 .

\section{Definition of research interest}

\subsection{Resilience assessment indicator}

The capacities of a road system to adapt to a variety of different stress scenarios is valuable to characterize and evaluate system's resilience (Ganin et al., 2017). Meanwhile, many researchers describe transport resilience through the non-functional requirements/properties like robustness, redundancy, reliability, vulnerability, etc. (Yang et al., 2020). Therefore, besides resilience, the assessment framework of several characteristics that can represent resilience capacity, like adaptation, robustness, redundancy, reliability, vulnerability, are equally noteworthy to our study.

A certain confusion shows around several similar or related vocabularies of indicator, like parameter and criteria. We find that many French assessment frameworks use these terms in a different way. For example, the "number of affected people" is considered as an indicator in "National Flood Vulnerability Framework" (Cerema, 2016), while it is called as an information of damage evaluation in Methodological guide "AFTER flooding" (Dantec and Pipien, 2019). Therefore, we need a set of standard definitions of the relevant terms in order to categorize, compare and discuss all identified indicators. In this paper, parameter is the data element to be taken into account when making a decision or a calculation. Indicator is the chosen information, associated with a criterion, intended to observe its evolution at defined intervals. Criterion is a character or a sign, which makes it possible to distinguish a thing, a concept, to make a judgment of appreciation.

\subsection{Road infrastructure and flood risk}

\subsubsection{Two objectives: consequence and reaction}

To analyse practical indicators of road infrastructure resilience to flood risk, we need to highlight the relationship between road infrastructure and floods. The term of "resilience" first introduced in Holling's study for ecological science in 1973. The UNISDR (2009) defines the resilience as "the ability of a system, community or society exposed to hazards to resist, absorb, accommodate, adapt to, transform and recover from the effects of a hazard in a timely and efficient manner". The resilience ability of a system refers to the effects of hazards to this system and the reactions (resist, absorb, accommodate, adapt to, transform and recover from) of this system facing hazards. Applying these definitions to our research, floods are the hazards, while road infrastructures are the affected systems.

Flood hazard represents the potential occurrence of a natural or human induced event, trend or physical impacts (IPCC, 2014). But a better resilience refers to less flood risks (not merely flood hazards), which refer to the combination of the probability of a flood event and of the potential adverse consequences in multidimensional scales associated with a flood event (EXCIMAP, 2007). RIs' resilience to flood risk depends on the effects of flood hazards and the reaction of road systems (See Figure 1). Many studies on infrastructure resilience aim to assess the capacities of a stand-alone road infrastructure system, which is the reaction of the affected system. However, considering the impact of hazards, we should also assess the consequences of floods to RIs. As a result, consequence and reaction are two objectives to assess infrastructure resilience to flood hazards.

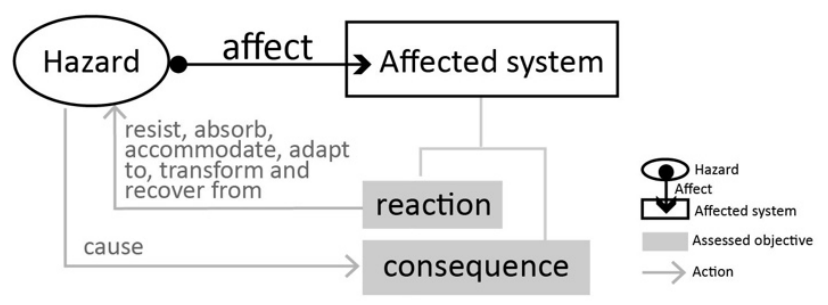

Figure 1: Assessed objectives in conceptual system of resilience, edited by the authors.

The reactions are the actions taken to ensure the performance, efficiency or safety of the system, planned either before a flood event (ex. alternative accessibility plans) or as an unplanned emergency response (ex. temporary evacuation of affected people). The consequence must exist in following hazards, as a product of the action of affected systems facing hazards. Consequences can include damage, time, cost, etc. related to affected system. Clarifying the "hazards" and the "affected systems" in a resilience study can help us 
identify the main French actors involved in RIs resilience indicators to floods risks in sector 3 and 4. Differs from scientific indicators that can be found in scientist websites (Yang et al., 2020), practical indicators are developed from operational indicators that apply on the administrative documents of government, or official reports of concerning actors (private or public). Based on these involved actors, we could search for the relevant documents and the indicators in them.

\subsubsection{Two affected system: RIs and Urban system}

Indeed, the dysfunction of road infrastructure, caused by floods, can affect urban system. Applying to NRR system, an order of effect can be demonstrated: Floods affect NRR, and then the dysfunction of NRR affects Nantes Metropole (see Figure 2). Meanwhile, another order should be highlighted: Floods affect Nantes territory, and then the dysfunction of Nantes territory affects NRR (see Figure 3). For example, heavy demands of centre city on rescue vehicles may cause traffic congestion on NRR network.
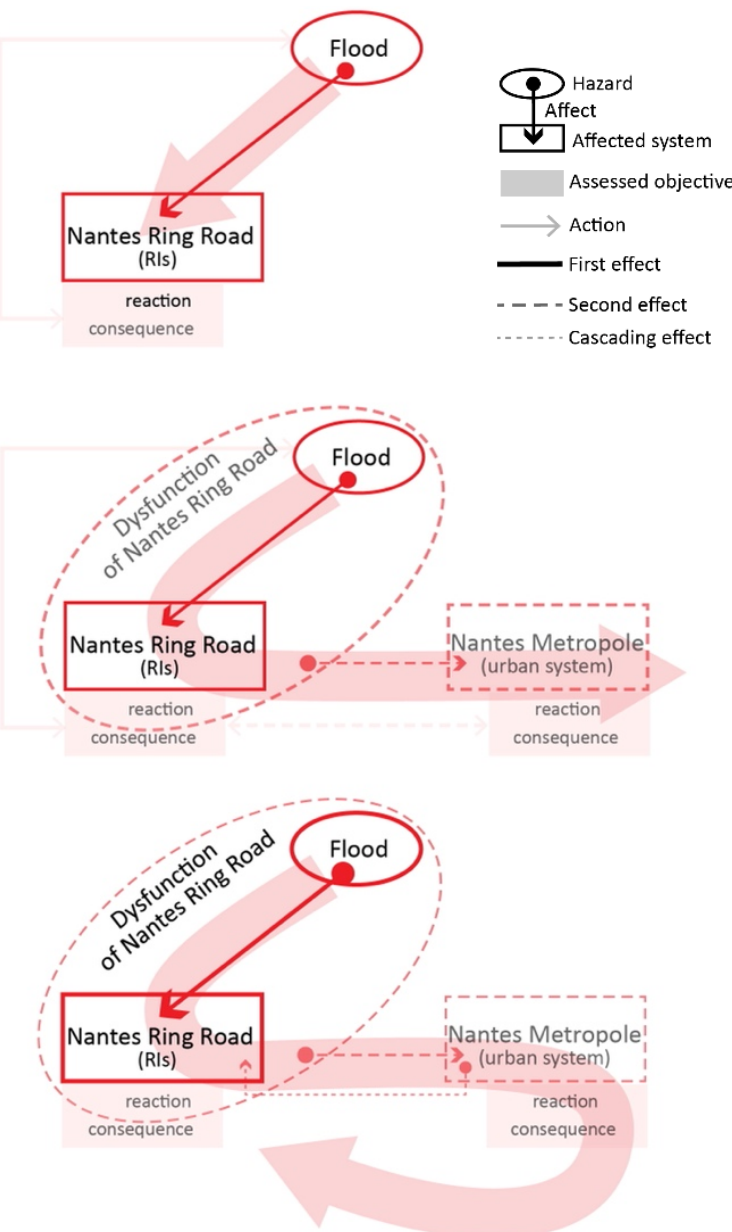

Figure 2: Direct and indirect effects of floods (1), edited by the authors.

Due to cascading effects, the Nantes territory, affected by NRR's dysfunction, can still influence NRR system. Equally, NRR system, affected by the dysfunction of Nantes territory, can still influence Nantes metropole. Therefore, the two targets (urban system and RIs) face the affect multi-dimensional and multi-level impact (see
Figure 4). In this paper, we focus on two affected systems, namely NRR and Nantes Metropole.
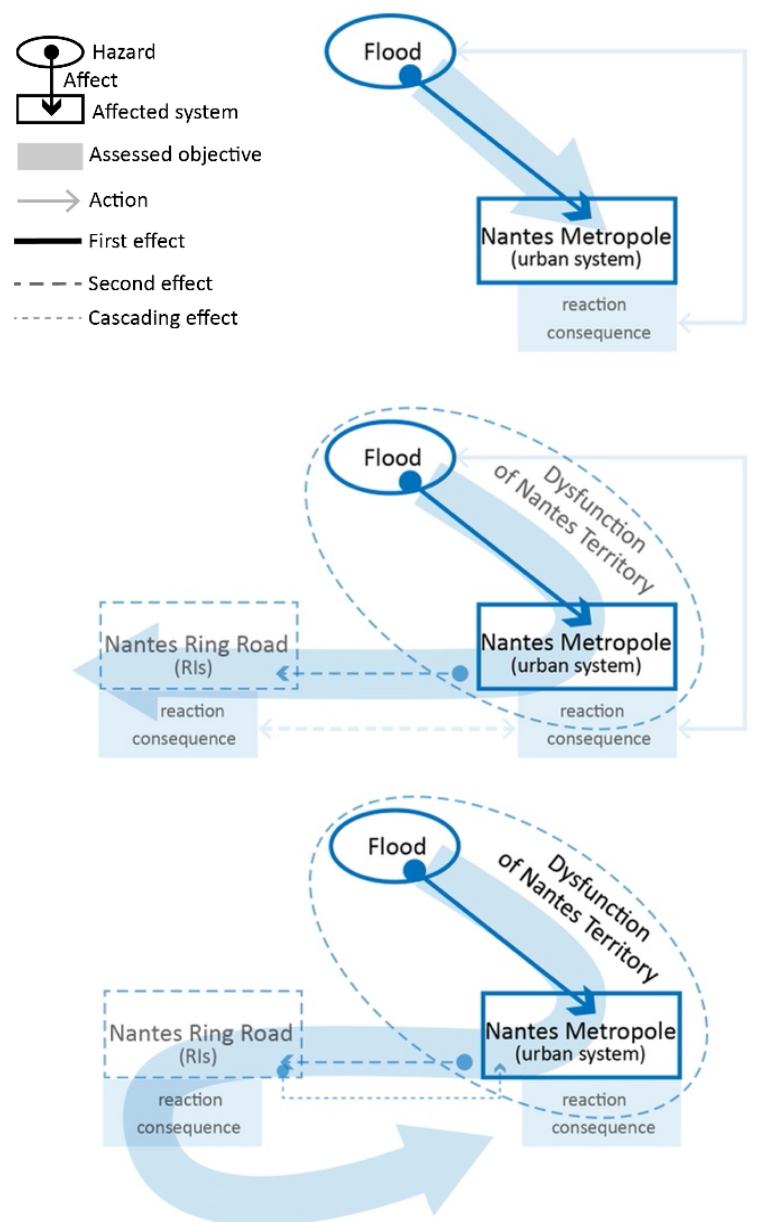

Figure 3: Direct and indirect effects of floods (2), edited by the authors.

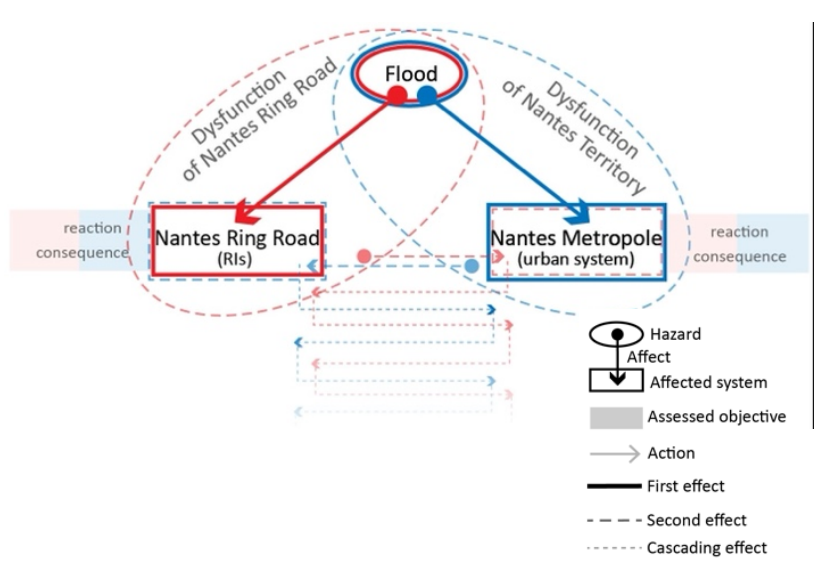

Figure 4: Affected systems in conceptual system of resilience, edited by the authors.

\section{Nantes Ring Road network and flood risks}

The case study of NRR Network is used to illustrate the building of practical indicators in local territorial management. As defined in Section 2, the actors associated with disasters and affected systems are key to the identification of indicators. In this section, we will 
therefore identify practical indicators from the documents of the actors involved floods and NRR.

With a length of 42 kilometres, the NRR have the services extending beyond the local level and are attractive in the region and even in the nation (DREAL Pays de la Loire, 2014). However, there is a flood risk of the Gesvres River on the section between the "Porte de la Chapelle" and the "Porte de la Beaujoire" (DREAL Pays de la Loire, 2016). Due to high use of the NRR network, flooding of this section could lead to the congestion on the connected roads, thus affect secondly Nantes Metropole. Nantes Metropole located in the west of France. It has a high concentration of population and economic and territorial issues potentially exposed to flooding. Including 11 dangerous municipalities, it has been determined as a High Flood Risk Area (TRI) by prefectural decree of 26 November 2012, because of the major flood event consequences at the national level (Nantes Métropole, 2017).

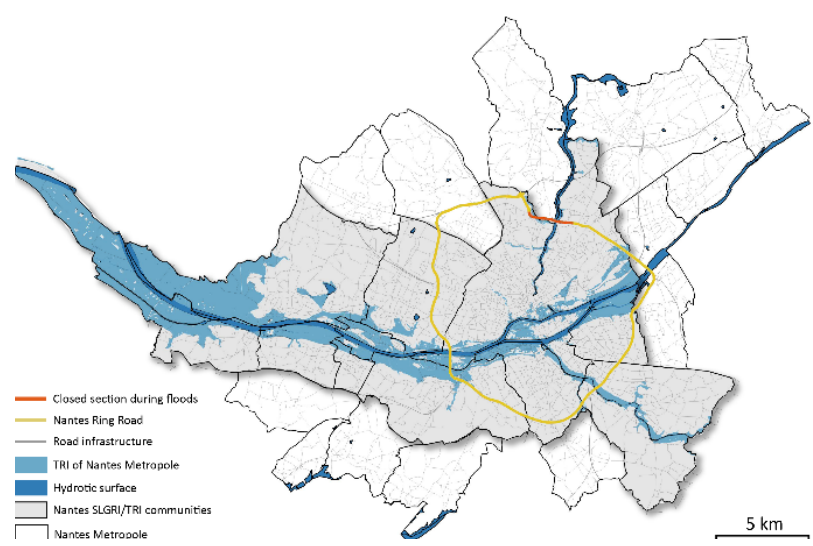

Figure 5: TRI and Road infrastructures in Nantes Metropole, figure design inspired by Nantes Metropole (2017) and DREAL Pays de la Loire (2016), edited by the authors

In road infrastructure management sector, the NRR network has been gradually developed under various project owners (State, General Council, Nantes Metropole Conurbation, Cofiroute), which has led to its relatively heterogeneous characteristics throughout its length. However, the main actors of RIs management aims to improve traffic flow and travel safety. This leads to their principal consideration of flood risks relating to the improvement of user information system, road education and freight transport safety. Although the discussion of NRR's resilience can be found in many practical documents (DREAL Pays de la Loire, 2016; DREAL Pays de Loire, 2014), a highlighted shortcoming is the incompleteness of the issues targeting assessing indicators of flood risks in them.

In the flood risks management sector, Nantes Metropole has a decision-making power of flood management. The Local Strategy for Flood Risk Management (SLGRI) of Nantes TRI (2017), published by Nantes Metropole, is a tool that aims at implementing the Flood Directive and allows local actors to focus on flood management referencing to local priorities and issues, including assessment of territorial vulnerability to flood risks. Nantes SLGRI uses the operational indicators, suggested in the document "National Flood Vulnerability Framework" as practical indicators to establish territorial diagnostic.

\begin{tabular}{|c|c|c|c|}
\hline Objective & Criterion & $\begin{array}{l}\text { Vulnerability } \\
\text { source }\end{array}$ & Indicator \\
\hline \multirow[t]{5}{*}{$\begin{array}{l}\text { Human } \\
\text { safety }\end{array}$} & \multirow{4}{*}{$\begin{array}{l}\text { Human } \\
\text { endanger } \\
\text { ment due } \\
\text { to } \\
\text { infrastruc } \\
\text { ture and } \\
\text { network } \\
\text { dysfuncti } \\
\text { ons }\end{array}$} & \multirow{2}{*}{$\begin{array}{l}\text { Water } \\
\text { presence in } \\
\text { the open } \\
\text { spaces/areas } \\
\text { in which } \\
\text { pedestrians or } \\
\text { vehicles } \\
\text { crossing } \\
\text { frequently }\end{array}$} & $\begin{array}{l}\text { Proportion of unlocked } \\
\text { manholes }\end{array}$ \\
\hline & & & $\begin{array}{l}\text { Number of roads } \\
\text { intercepted by hazard } \\
\text { zones dangerous for } \\
\text { people }\end{array}$ \\
\hline & & $\begin{array}{l}\text { Dangerousnes } \\
\mathrm{s} \text { of access } \\
\text { routes to } \\
\text { dwellings } \\
\end{array}$ & $\begin{array}{l}\text { Number of inhabitants in } \\
\text { areas accessible by } \\
\text { dangerous roads }\end{array}$ \\
\hline & & $\begin{array}{l}\text { Prolonged } \\
\text { isolation of } \\
\text { populated } \\
\text { neighbourhoo } \\
\text { ds }\end{array}$ & $\begin{array}{l}\text { Number of people in } \\
\text { long urbanised areas } \\
\text { inaccessible and not } \\
\text { organised for on-site } \\
\text { maintenance }\end{array}$ \\
\hline & $\begin{array}{l}\text { Human } \\
\text { endanger } \\
\text { ment } \\
\text { linked to } \\
\text { over- } \\
\text { hazards }\end{array}$ & $\begin{array}{l}\text { Overwater } \\
\text { generated by } \\
\text { a linear } \\
\text { structure } \\
\text { (road, dike, } \\
\text { dam) or ice } \\
\text { jams }\end{array}$ & $\begin{array}{l}\text { Number of people } \\
\text { exposed to over-hazard } \\
\text { linked to structures } \\
\text { rupture }\end{array}$ \\
\hline \multirow[t]{4}{*}{$\begin{array}{l}\text { Damage } \\
\text { cost }\end{array}$} & $\begin{array}{l}\text { Damage } \\
\text { to } \\
\text { activities } \\
\text { /property }\end{array}$ & $\begin{array}{l}\text { Destruction } \\
\text { or damage to } \\
\text { vehicles }\end{array}$ & $\begin{array}{l}\text { Number of (land) } \\
\text { vehicles exposed to the } \\
\text { hazard. }\end{array}$ \\
\hline & \multirow[t]{3}{*}{$\begin{array}{l}\text { Damage } \\
\text { to } \\
\text { infrastruc } \\
\text { ture and } \\
\text { urban } \\
\text { networks }\end{array}$} & \multirow[t]{2}{*}{$\begin{array}{l}\text { Erosion, } \\
\text { destruction, } \\
\text { deposits on } \\
\text { infrastructure }\end{array}$} & $\begin{array}{l}\text { Number of parts of } \\
\text { networks (nodes, flows) } \\
\text { that can be spaces, } \\
\text { structures and networks } \\
\text { (erosion, waste, etc.) } \\
\text { damaged by flooding }\end{array}$ \\
\hline & & & $\begin{array}{l}\text { Damage to roads } \\
\text { depending on the height } \\
\text { of submersion. }\end{array}$ \\
\hline & & $\begin{array}{l}\text { Damage due } \\
\text { to } \\
\text { dysfunctions } \\
\text { of urban } \\
\text { networks }\end{array}$ & $\begin{array}{l}\text { Lack of indicators (the } \\
\text { characterisation of this } \\
\text { source requires urban } \\
\text { networks specific } \\
\text { network expertise.) }\end{array}$ \\
\hline \multirow[t]{6}{*}{$\begin{array}{l}\text { Return to } \\
\text { normality }\end{array}$} & \multirow{6}{*}{$\begin{array}{l}\text { Restorati } \\
\text { on of } \\
\text { infrastruc } \\
\text { ture and } \\
\text { networks }\end{array}$} & \multirow{4}{*}{$\begin{array}{l}\text { Ability of } \\
\text { managers to } \\
\text { maintain or } \\
\text { restore the } \\
\text { infrastructure } \\
\text { operation }\end{array}$} & $\begin{array}{l}\text { Proportion of } \\
\text { infrastructures with a } \\
\text { crisis management plan }\end{array}$ \\
\hline & & & $\begin{array}{l}\text { Number of vehicles/day } \\
\text { unable to travel on } \\
\text { transit networks, taking } \\
\text { into account alternative } \\
\text { routes }\end{array}$ \\
\hline & & & $\begin{array}{l}\text { Proportion of local } \\
\text { service networks } \\
\text { affected }\end{array}$ \\
\hline & & & $\begin{array}{l}\text { Time required all } \\
\text { transport networks to } \\
\text { return to normal } \\
\text { operation }\end{array}$ \\
\hline & & \multirow[t]{2}{*}{$\begin{array}{l}\text { Ability to } \\
\text { maintain or } \\
\text { rehabilitate } \\
\text { protective } \\
\text { structures }\end{array}$} & $\begin{array}{l}\text { Proportion of protective } \\
\text { structures not covered by } \\
\text { an emergency response } \\
\text { system }\end{array}$ \\
\hline & & & $\begin{array}{l}\text { Deadline for emergency } \\
\text { intervention }\end{array}$ \\
\hline
\end{tabular}

Table 1: Summarized indicators in National Flood Vulnerability Framework, source: Cerema (2016) 
This document was produced upon request of the DGPR of the Ministry of Environment, Energy and Sea (MEEM) for proposing a vulnerability assessment framework and a method to build an operational action plan. We can say that the currently used practical indicators in Nantes metropole become from the operational indicator in a flood management document, realised by a national administrative institution. The practical indicators in Nantes are based on three objectives of the SNGRI: improve human safety, reduce damage to property and improve the return to normality. In order to assess national vulnerability easily, the framework provides a breakdown for each objective by identifying several criterions that can be assimilated to vulnerability sub-themes. For a given criterion, this document specifies different vulnerability source and indicators that reflect structural, organisational or population profile-related weaknesses (see Table 1).

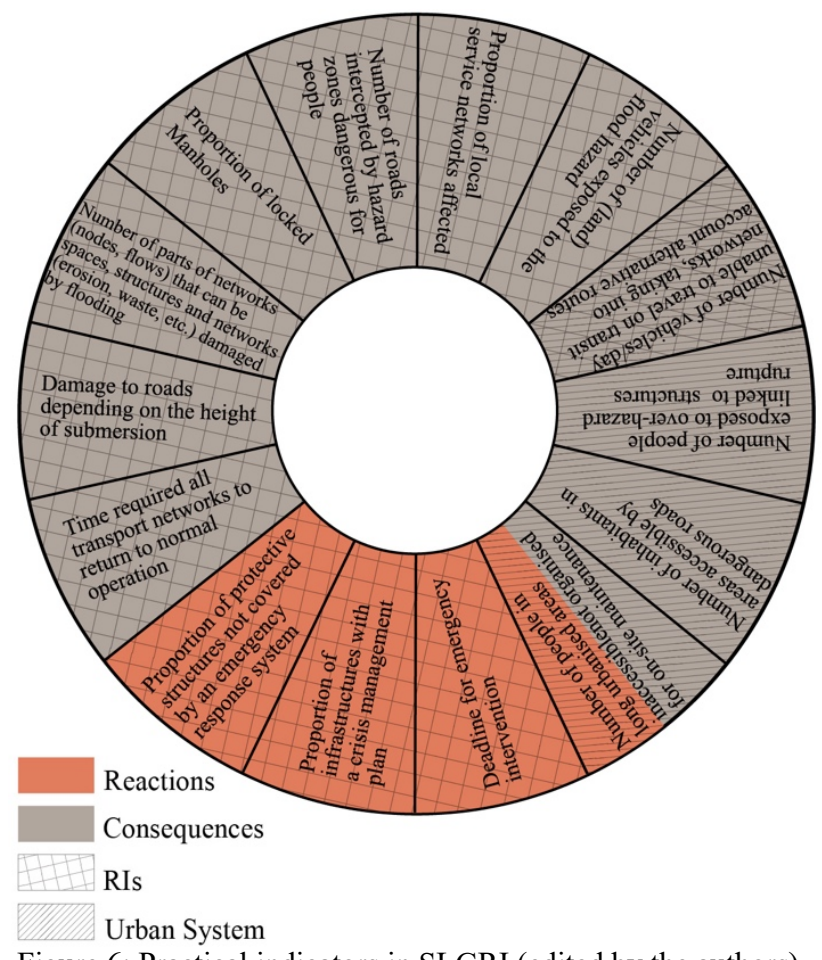

Figure 6: Practical indicators in SLGRI (edited by the authors)

Following the research interest in section two (assessed objectives, affected systems), we categorize these practical indicators in Figure 6. We find that most indicators focus on the consequences in two levels, direct and indirect effect. Few indicators aim at assessing the reactions of NRR network and no indicator assesses the reactions of Nantes territory. Therefore, in the next section chapters, in reviewing the selected documents, we can focus more on the operational indicators that assess the reactions of road network and urban territory.

\section{Main actors involved in management}

Because of a strong tradition of centralisation, the central State of France is comparatively powerful, but its organisation is decentralised from a constitutional point of view (Larrue et al., 2016). Therefore, French public or private actors are diverse in complex hierarchies and multi-levels geographical scales. Considering our research goal, we can note several institutions related both RIs and floods management, such as DREAL, Cerema. Nevertheless, each French institution in different sectors has its own specific functions, which makes it difficult to find documents or reports both focusing on RIs and floods risk. This means that we should study the documents of flood management and find out about RIs. It is also necessary to look at the documents of RIs management to find out about flood risks.

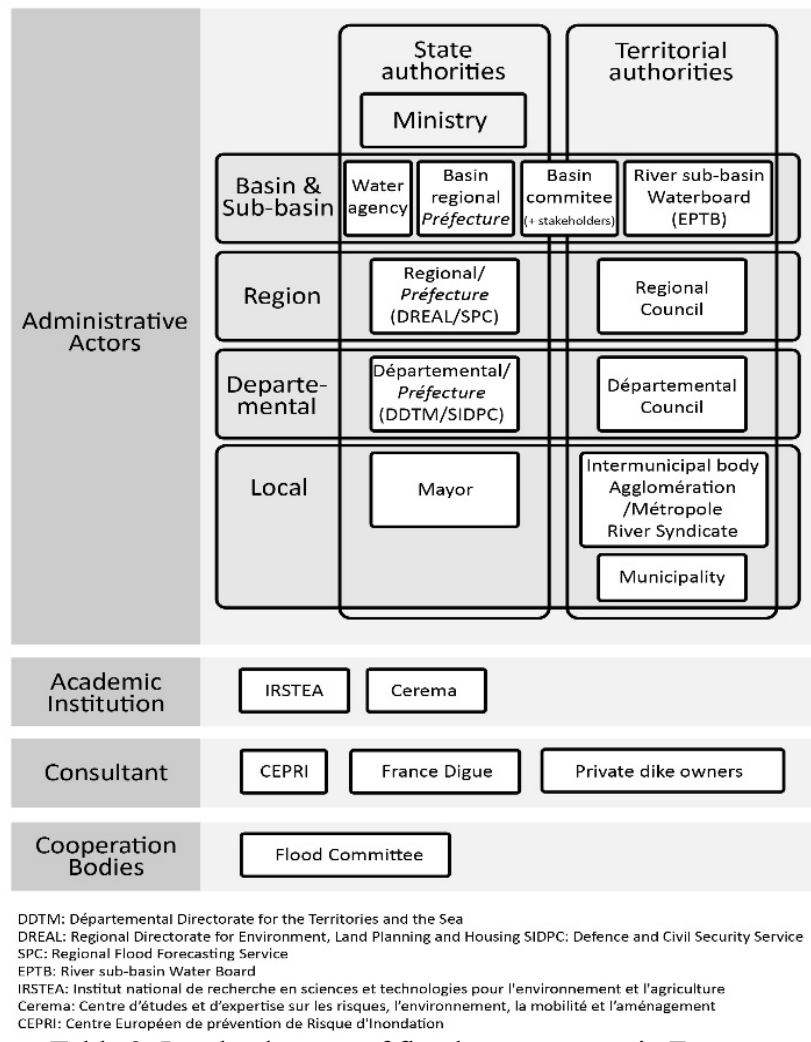

Table 2: Involved actors of flood management in France, source: (Larrue et al., 2016)

Regarding the flood risk policy, France has two main types of public authorities, State services (executive power) and territorial authorities (decision-making power). Larrue et al. (2016) argued that the decentralisation gives each local authority "the power to make decisions beyond the areas of competence which are expressly attributed to it by law, if the decision is justified by a local public interest." From national scale to local scale, the French administrative structure of flood risks is based on five state service levels and four territorial levels (see Table 2). The special zoning approach in French is that the national territory has been divided into six large river basin corresponding to the areas of jurisdiction of the six water agencies. In this administrative structure (Table 2 ), municipalities and intermunicipal bodies (EPCI) are considered vital because flood risk management in France is mainly implemented on the local scale (with sub-basin collaboration being discretionary) (Priest et al., 2016). Additionally, we take into account some academic agencies and consultants whose report can be possible to disseminate and share significant contribution in France. The operational indicators promoted by these institutions 
in Table 2 can be converted into practical indicators after validation by the local authorities who have the related powers. For example, the power of local authorities on natural risk management makes Nantes metropole responsible for writing Nantes SLGRI where we find the Nantes practical indicators borrowing from academic agency Cerema (2016).

In French road infrastructure management, different actors, consulted by the Minister for transport (part of Minister of Ecology), are responsible for the maintenance, operation or safety of roads. Four levels of road infrastructure actors are applied to four types of road (see Table 3). According to Etablissement Public Loire (2006), the fact that a large number of actors are in charge of roadways results in difficulties to understand the responsibilities of prevention and the production. For that reason, road infrastructure management to flood risks became complicated and confusing. In addition, due to decentralisation, the authorities and powers are partly transferred from the state services to the local general Councils and road management of flood risk is therefore taken into account very differently from one manager to another (Etablissement Public Loire, 2006), for example significant differences from one municipal to another in view of dissimilar climate. This requires more specific management methods, based on the particular context of each region.

\begin{tabular}{|c|c|c|c|}
\hline & $\begin{array}{l}\text { Responsible } \\
\text { public } \\
\text { authority }\end{array}$ & Decision-maker & $\begin{array}{l}\text { Construction } \\
\text { services and } \\
\text { road manager }\end{array}$ \\
\hline $\begin{array}{l}\text { Concession } \\
\text { highways }\end{array}$ & State & $\begin{array}{l}\text { Minister for } \\
\text { Transport } \\
\text { (Directorate- } \\
\text { General for } \\
\text { Infrastructure, } \\
\text { Transport and } \\
\text { the Sea DGITM) }\end{array}$ & $\begin{array}{l}\text { Concession } \\
\text { companies }\end{array}$ \\
\hline $\begin{array}{l}\text { Unconcessioned } \\
\text { highways and } \\
\text { national roads }\end{array}$ & State & $\begin{array}{l}\text { Minister for } \\
\text { Transport } \\
\text { (Directorate- } \\
\text { General for } \\
\text { Infrastructure, } \\
\text { Transport and } \\
\text { the Sea DGITM) }\end{array}$ & $\begin{array}{l}\text { Interdepartmental } \\
\text { Road Directorates } \\
\text { (DIR) } \\
\text { Regional Project } \\
\text { Management } \\
\text { Service (SMO) }\end{array}$ \\
\hline $\begin{array}{l}\text { Departmental } \\
\text { roads }\end{array}$ & Department & $\begin{array}{l}\text { Departmental } \\
\text { council }\end{array}$ & $\begin{array}{c}\text { Department } \\
\text { technical services }\end{array}$ \\
\hline $\begin{array}{l}\text { Municipal } \\
\text { roads }\end{array}$ & Municipality & $\begin{array}{l}\text { Municipal } \\
\text { council }\end{array}$ & $\begin{array}{c}\text { Municipal } \\
\text { technical services }\end{array}$ \\
\hline
\end{tabular}

Table 3: Involved actors of road infrastructure management in France, source: France Ministry of Ecology

\section{Selection of documents and operational indicators}

Based on the study subject defined in section 2, after an extensive review of the published documents by main French actors in charge of floods and road infrastructures, six documents were selected (see Table 4). They allow us to identify operational indicators applied on the case study in next section.

\subsection{Overview of indicators}

1) Territory and its technical networks faced with the flooding risk

This document was published by CERPI in 2016. One of the emphasized objects is presenting the links between territorial and technical networks vulnerability. According to its explanation, technique network resilience requires a strong political backing to support technical choices adapted to the context of development and continuous improvement of the territory. Therefore, it uses the nature (availability and types) of existing solutions, applied to decrease vulnerability and to manage vulnerability, for assessing the technical networks management measures. The solutions could be the guide to reduce or respond to systems' vulnerabilities, like diverting sources, controlling solicitations.

2) Multi-criteria analysis of flood prevention projects: the methodological guide

This guide is an update of the AMC National Flood Guide for July 2014. It was organized by the General Commission for Sustainable Development (CGDD) under the project management of the Ministerial Directorate for Risk Prevention (DGPR). It highlights that the Daily traffic of transport networks in inundation areas should be used to provide information on the vulnerability of networks in terms of impacted traffic. The indicator, Daily traffic of transport networks in inundation areas, evaluates the indirect damage from flood risk to road transport networks. In addition, the total damages take into account five elements: travel choice, travel mode, daily time, travel number on diversion route (defined by the authorities), congestion and submerged water level.

3) Preliminary Flood Risk Assessment (EPRI) of Loire-Bretagne Basin

The EPRI aims at assessing the potential risks associated with flooding risks at the large Loire-Bretagne river basin (or district). Assessing the potential impacts of future, highlighted objectives in this document, is based on 1) assessing potential flood areas and 2) describing the damage of affected elements (human, infrastructure, activities, etc.) as indicators, which can be potentially impacted by future floods. It argued that flooding cannot cause flood risks if flood risks have not potential consequences to human health, the environment, cultural heritage and economic activity associated with a flood event (EXCIMAP, 2007). Concerning road infrastructure resilience, transport network lines in the Constitution of Envelopes Approached to Potential Floods (EAIP) can be used to evaluate economic impact.

4) Methodological guide "AFTER flooding", Organisation of the data collection from the flood REXs

Following the order from the Minister of DGPR, the CGEDD and Cerema led a working group with a view to proposing this methodological guide entitled "AFTER flooding" to better capitalise on feedback from experience in flood prevention. For better guiding future actions and choices of stakeholder, it emphasizes the necessity of damage evaluation for properties and activities located in flooding territory, including road infrastructure. The damage on road infrastructure can be based on the 
following indicators: list of rupture networks/lines, location on the map, description of the damage (destruction, submersion, etc.), rupture duration, number of affected people, consequences (in particular on disaster management). In addition, impact on a wider scale (health impact, economic, etc.) makes a connection between the indicator of indirect victim number and infrastructure resilience evaluation.

\begin{tabular}{|c|c|c|c|c|}
\hline $\begin{array}{l}N \\
0\end{array}$ & Name & $\begin{array}{l}\text { Editor or } \\
\text { auteur }\end{array}$ & $\begin{array}{l}\text { Identified } \\
\text { target of } \\
\text { indicators }\end{array}$ & $\begin{array}{l}\text { Identified } \\
\text { Indicators }\end{array}$ \\
\hline 1 & $\begin{array}{l}\text { Territory and } \\
\text { its technical } \\
\text { networks } \\
\text { faced with the } \\
\text { flood risk }\end{array}$ & $\begin{array}{l}\text { CEPRI, } \\
\text { (2016) }\end{array}$ & $\begin{array}{l}\text { Infrastructure } \\
\text { vulnerability } \\
\text { to flood risk }\end{array}$ & $\begin{array}{l}\text { Availability and } \\
\text { types of existing } \\
\text { solutions in } \\
\text { risks } \\
\text { management }\end{array}$ \\
\hline 2 & $\begin{array}{l}\text { Multi-criteria } \\
\text { analysis of } \\
\text { flood } \\
\text { prevention } \\
\text { projects: the } \\
\text { methodologic } \\
\text { al guide }\end{array}$ & $\begin{array}{l}\text { CGDD } \\
(2018)\end{array}$ & $\begin{array}{l}\text { Floods } \\
\text { indirect } \\
\text { damage to } \\
\text { daily traffic }\end{array}$ & $\begin{array}{l}\text { Daily traffic of } \\
\text { transport } \\
\text { networks in } \\
\text { flood risk areas }\end{array}$ \\
\hline 3 & $\begin{array}{l}\text { EPRI of } \\
\text { Loire- } \\
\text { Bretagne } \\
\text { Basin } \\
\end{array}$ & $\begin{array}{l}\text { DREAL } \\
\text { Centre } \\
(2011)\end{array}$ & $\begin{array}{l}\text { Flood risks on } \\
\text { transport } \\
\text { network }\end{array}$ & $\begin{array}{l}\text { Transport } \\
\text { network lines in } \\
\text { inundation area }\end{array}$ \\
\hline 4 & $\begin{array}{l}\text { Methodologic } \\
\text { al guide } \\
\text { "AFTER } \\
\text { flooding" }\end{array}$ & $\begin{array}{l}\text { CGEDD, } \\
\text { Cerema, } \\
\text { (Dantec } \\
\text { and } \\
\text { Pipien, } \\
\text { 2019) }\end{array}$ & $\begin{array}{l}\text { Damage on } \\
\text { road } \\
\text { infrastructure } \\
\text { from floods }\end{array}$ & $\begin{array}{l}\text { Rupture } \\
\text { networks/lines, } \\
\text { location to } \\
\text { flooding, } \\
\text { description of } \\
\text { the damages, } \\
\text { rupture } \\
\text { duration, } \\
\text { number of } \\
\text { affected people, } \\
\text { damage on } \\
\text { disaster rescue } \\
\text { plan }\end{array}$ \\
\hline 5 & $\begin{array}{l}\text { PNACC, } \\
\text { infrastructure } \\
\text { and transport } \\
\text { system } \\
\text { component }\end{array}$ & $\begin{array}{l}\text { Cerema } \\
(2015)\end{array}$ & $\begin{array}{l}\text { Functional } \\
\text { criticality of } \\
\text { road } \\
\text { infrastructure }\end{array}$ & $\begin{array}{l}\text { Interrupted } \\
\text { accessibility, } \\
\text { reduced } \\
\text { performance, } \\
\text { consequences of } \\
\text { multiple } \\
\text { ruptures }\end{array}$ \\
\hline 6 & $\begin{array}{l}\text { Unavailability } \\
\text { of transport } \\
\text { infrastructure, } \\
\text { Measuring } \\
\text { and reducing } \\
\text { costs }\end{array}$ & $\begin{array}{l}\text { CGDD } \\
(2017)\end{array}$ & $\begin{array}{l}\text { Socio- } \\
\text { economic } \\
\text { cost due to } \\
\text { unavailability } \\
\text { of transport } \\
\text { infrastructure }\end{array}$ & $\begin{array}{l}\text { Increased } \\
\text { distance, } \\
\text { increased time } \\
\text { spent on the } \\
\text { road, increased } \\
\text { local pollution, } \\
\text { increased } \\
\text { insecurity }\end{array}$ \\
\hline
\end{tabular}

Table 4: Basic information from selected documents

5) PNACC, infrastructure and transport system component

In response to climate change, France has adopted a National Plan for Adaptation to Climate Change (PNACC) for transport infrastructures and systems. The third report (PNACC-action 3) aims to suggest methodology for analysing infrastructure vulnerability associated with extreme weather events. It explains the principal function of transport network on serving its users to move around in good conditions, or to transport freight. Functional criticality analysis can identify the impact of failures on network performance, thus to assess network's vulnerability. Three following indicators can identify the functional criticality: interrupted accessibility, reduced performance, and consequences of multiple ruptures.

6) Unavailability of transport infrastructure, Measuring and reducing costs

This document aims at measuring damage on transport infrastructure with a socio-economic perspective. Based on our indicator definition in section 2, the "socioeconomic cost" functioned as an indicator in Unavailability of transport infrastructure, even though the term "indicator" did not show up throughout the document. Counting full community cost of a transport infrastructure failure and assessing its vulnerability to various risk factors are useful to better plan investments to reinforce existing networks. In the road transport sector, it suggests measuring total generalised costs of the whole network and different sections. Details of socio-economic cost indicators include increased distance, increased time spent on the road, increased local pollution $\left(\mathrm{CO}_{2}\right.$ emissions), increased insecurity, etc.

\subsection{Discussion}

With the same method used in section 3, we categorize these organisational indicators (see Figure 7) following the study' interest in section two (assessed objective, affected systems) and compare them with the practical indicators in Nantes SLGRI (see Figure 6).

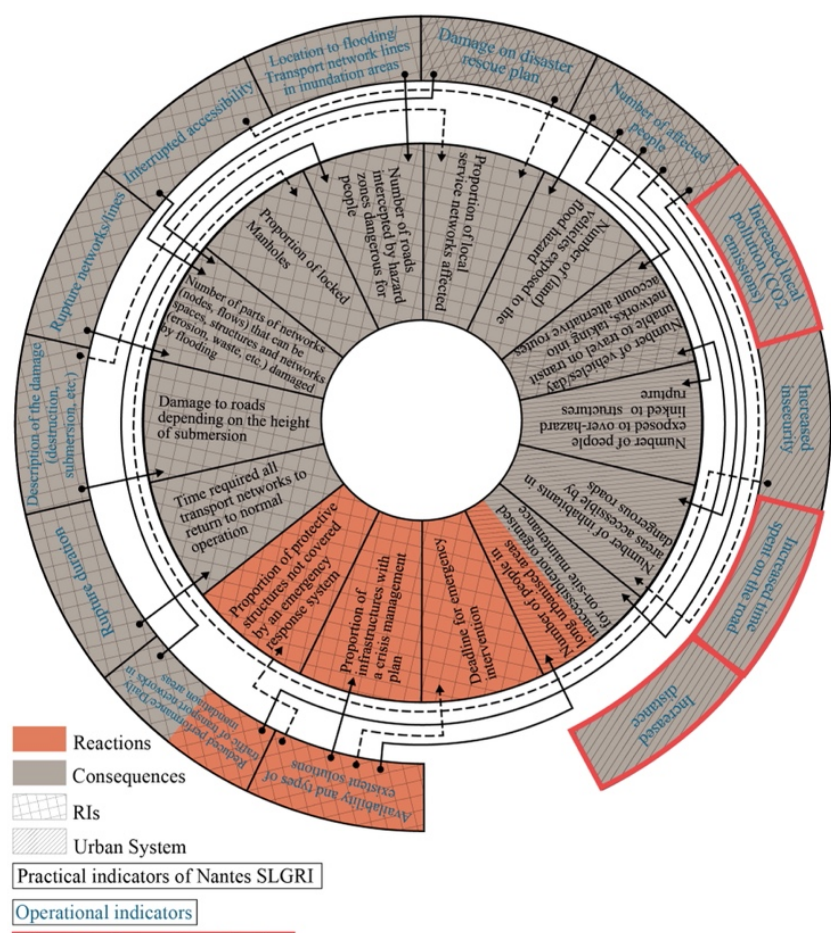

Selected indicators for application

Figure 7: Comparison between practical indicators in Nantes SLGRI and selected operational indicators, edited by the authors.

Excluding those that are similar to the practical indicators (shown in Figure 7 with a black line), we identify three operational indicators deserving applications: increased distances, increased spend time on the road, increased local pollution. The three identified 
operational indicators filled the lack of Nantes practical indicators in assessing time (increased spend time) and cost (increased distances) of the consequences in the urban system, and even involved ecological (increased local pollution). These indicators are all directly or indirectly related. For example, the increase in distance leads to an increase in travel time, which in turn increases $\mathrm{CO}_{2}$ emissions.

\section{Indicators' application on case study}

Before applying these three indicators (increased distances, increased times spend on the road, increased local pollution) on Nantes Ring Road facing flood risks, we need to define the objects of our study:

- The sections of NRR system affected frequently by the flooding;

- The alternative routes replacing the affected section during flooding events

Their distances, times spent on the road and $\mathrm{CO}_{2}$ emissions will be compared.

The flood risk on NRR exist on the section between the "Porte de la Chapelle" (Point B in Figure 8) and the "Porte de la Beaujoire"(Point $C$ in Figure 8). When this section is closed, several suggested alternative routes could be activated (DIRO, 2015) (See Figure 8, number 1). Therefore, during a flood event, the green paths in Figure 8 are suggested for the inside direction, while the blue paths are suggested for the outside direction.

Although the drivers may choose other routes according to their own situations (like destinations, emotions, driving habits, etc.), the alternative routes suggested by DIRO are the easiest and most efficient alternative routes to the closed NRR section. Therefore, we define the alternative routes of DIRO and the sections that they replace as our study objects. Consequently, we obtain eight paths to investigate (see Table 5 and Figure 8, number 3.4.5.6).

\begin{tabular}{|c|c|c|c|c|c|}
\hline & $\begin{array}{l}\text { Start } \\
\text { point }\end{array}$ & $\begin{array}{c}\text { Arrival } \\
\text { point }\end{array}$ & $\begin{array}{c}\text { Map } \\
\text { number } \\
\text { (Figure 8) }\end{array}$ & $\begin{array}{l}\text { Given } \\
\text { situation }\end{array}$ & $\begin{array}{l}\text { Path } \\
\text { number }\end{array}$ \\
\hline \multirow{4}{*}{$\begin{array}{l}\text { Outside } \\
\text { direction }\end{array}$} & \multirow[t]{2}{*}{$\mathrm{C}$} & \multirow[t]{2}{*}{ A } & \multirow[t]{2}{*}{3} & Normal & $\mathrm{N}, \mathrm{o}, 1$ \\
\hline & & & & Flooding & $\mathrm{F}, \mathrm{o}, 1$ \\
\hline & \multirow[t]{2}{*}{$\mathrm{D}$} & \multirow[t]{2}{*}{$\mathrm{A}$} & \multirow[t]{2}{*}{4} & Normal & $\mathrm{N}, \mathrm{o}, 2$ \\
\hline & & & & Flooding & $\mathrm{F}, \mathrm{o}, 2$ \\
\hline \multirow{4}{*}{$\begin{array}{l}\text { Inside } \\
\text { direction }\end{array}$} & \multirow[t]{2}{*}{ B } & \multirow[t]{2}{*}{$\mathrm{D}$} & \multirow[t]{2}{*}{5} & Normal & $\mathrm{N}, \mathrm{i}, 1$ \\
\hline & & & & Flooding & $\mathrm{F}, \mathrm{i}, 1$ \\
\hline & \multirow[t]{2}{*}{$\bar{A}$} & \multirow[t]{2}{*}{$\mathrm{D}$} & \multirow[t]{2}{*}{6} & Normal & $\mathrm{N}, \mathrm{i}, 2$ \\
\hline & & & & Flooding & $\mathrm{F}, \mathrm{i}, 2$ \\
\hline
\end{tabular}

Table 5: Description of studied eight paths.

Next, the following four steps are applied, all based on local databased and carried out in GIS system:

1. Calculate the distances of each path

2. Calculate their spent times in observing the road speed limits set in Nantes (see Figure 8, number 2 ). We specify $110 \mathrm{~km} / \mathrm{h}$ for roads with unlimited speed.

3. Calculate their $\mathrm{CO}_{2}$ emissions following the French public data (L'environnement en France, 2019) that estimates the average unit emissions of all French vehicles is $166 \mathrm{~g} / \mathrm{km}$.
4. Calculate the growth rate $G R(t, s, a)$ that is the increased distance (or travel time, $\mathrm{CO}_{2}$ emission) as a percentage of the distance (or travel time, $\mathrm{CO} 2$ emission) in normal situation. GR is equal to

$\frac{\text { Travel in flooding }(F)-\text { Tarvel in normal situation }(N)}{\text { Tarvel in }} \times 100$

Therefore, $G R(t, s, a)$ of the assed Target $t$ (distance, time, or $\mathrm{CO}_{2}$ emission), from Start point $s$ to Arrival point $a$. is defined as

$$
G R(t, s, a)=\frac{x\left(F, d, n^{\circ}\right)-x\left(N, d, n^{\circ}\right)}{x\left(N, d, n^{\circ}\right)} \times 100
$$

Where $x\left(F, d, n^{\circ}\right)$ is, in Flood situation, the value of target $t$, on $n$ alternative route for $d$ direction.

$x\left(N, d, n^{\circ}\right)$ is, in Normal situation, the value of target $t$, for $d$ direction on NRR section that replaced by $n$ alternative route. We highlight that:

- $\quad t$ presents the assessed Target: distance, time, or $\mathrm{CO}_{2}$ emission

- $\quad s$ presents the Start point: A, B, C or D in the Figure 8

- $\quad a$ presents the Arrival point: A, B, C or D in the Figure 8

- $\quad d$ presents the road Direction: $o$ (outside direction) or $I$ (inside direction).

- $\quad n$ presents the alternative road Number: 1 or 2

For example, the increased distance, from start point $\mathrm{C}$ to arrival point $\mathrm{A}$ (first alternative road for inside direction, see Figure 8, Number 3), is defined as:

$$
G R(\text { distance }, C, A)=\frac{x(F, o, 1)-x(N, o, 1)}{x(N, o, 1)} \times 100
$$

The increased time, from start point B to arrival point D (first alternative road for outside direction, see Figure 8, Number 5), is defined as:

$$
G R(\text { time }, B, D)=\frac{x(F, i, 1)-x(N, i, 1)}{x(N, i, 1)} \times 100
$$

The results are given in Table 6. The distances $\left(\mathrm{CO}_{2}\right.$ emissions $)$ of the paths with flood risks are 2.1 to 3.1 times the distance $\left(\mathrm{CO}_{2}\right.$ emissions $)$ of the paths without flood risks. Related to travel times, these data become 2.4 to 3.6 times. In particular, the trip from point B to point D has a growth rate of $209 \%$ in distance and $265 \%$ in travel time. The smallest growth in distance is from point $\mathrm{A}$ to point $\mathrm{D}$, with a growth rate of $215 \%$. The smallest growth time concerns the trip from point $\mathrm{D}$ to point $\mathrm{A}$, with a growth rate of $246 \%$.

In this paper, we primarily consider that the section of NRR is more resilient when its alternative cause less Growth Rate. Consequently, after an application of the selected indicators, the resilience of 
the four sections on the NRR to flood risks can be ranked as following (from highest to lowest):

1. Inside section between A-D and outside section between D-A (they have similar results)

2. Outside section between $\mathrm{C}-\mathrm{A}$

3. Inside section between B-D

\begin{tabular}{|l|l|l|l|l|l|}
\hline $\begin{array}{l}\text { Start and } \\
\text { arrival } \\
\text { point }\end{array}$ & Paths & $\begin{array}{l}\text { Distance } \\
(\mathrm{m})\end{array}$ & $\begin{array}{l}\text { Travel } \\
\text { time }\end{array}$ & $\begin{array}{l}\mathrm{CO}_{2} \\
\text { emission } \\
(\mathrm{g})\end{array}$ & $\begin{array}{l}\text { Cost } \\
(€)\end{array}$ \\
\hline \multirow{4}{*}{$\mathrm{C}-\mathrm{A}$} & $\mathrm{N}, \mathrm{o}, 1$ & 3676 & $\begin{array}{l}2 \mathrm{~min} \\
46 \mathrm{~s}\end{array}$ & 610 & 1.23 \\
\cline { 2 - 6 } & $\mathrm{F}, \mathrm{o}, 1$ & 9732 & $\begin{array}{l}8 \mathrm{~min} \\
17 \mathrm{~s}\end{array}$ & 1615 & 3.26 \\
\cline { 2 - 6 } & $\mathrm{GR}$ & $165 \%$ & $200 \%$ & $165 \%$ & $165 \%$ \\
\hline \multirow{5}{*}{$\mathrm{D}-\mathrm{A}$} & $\mathrm{N}, \mathrm{o}, 2$ & 4867 & $\begin{array}{l}3 \mathrm{~min} \\
40 \mathrm{~s}\end{array}$ & 808 & 1.63 \\
\cline { 2 - 6 } & $\mathrm{F}, \mathrm{o}, 2$ & 10536 & $\begin{array}{l}9 \mathrm{~min} \\
00 \mathrm{~s}\end{array}$ & 1749 & 3.53 \\
\cline { 2 - 6 } & $\mathrm{GR}$ & $116 \%$ & $146 \%$ & $116 \%$ & $116 \%$ \\
\hline \multirow{5}{*}{$\mathrm{B}-\mathrm{D}$} & $\mathrm{N}, \mathrm{i}, 1$ & 3605 & $\begin{array}{l}2 \mathrm{~min} \\
42 \mathrm{~s}\end{array}$ & 598 & 1.21 \\
\cline { 2 - 6 } & $\mathrm{F}, \mathrm{i}, 1$ & 11125 & $\begin{array}{l}9 \mathrm{~min} \\
50 \mathrm{~s}\end{array}$ & 1847 & 3.73 \\
\cline { 2 - 6 } & $\mathrm{GR}$ & $209 \%$ & $265 \%$ & $209 \%$ & $209 \%$ \\
\hline \multirow{4}{*}{ A-D } & $\mathrm{N}, \mathrm{i}, 2$ & 4731 & $\begin{array}{l}3 \mathrm{~min} \\
32 \mathrm{~s}\end{array}$ & 785 & 1.58 \\
\cline { 2 - 6 } & $\mathrm{F}, \mathrm{i}, 2$ & 10151 & $\begin{array}{l}8 \mathrm{~min} \\
53 \mathrm{~s}\end{array}$ & 1685 & 3.40 \\
\cline { 2 - 6 } & GR & $115 \%$ & $151 \%$ & $115 \%$ & $115 \%$ \\
\hline
\end{tabular}

Table 6: Results of selected operational indicators applied on RNN network.

In spite of our approach mentioned above, a better research can be refined with more Nantes local resources. For example, with the daily traffic flow on original sections and the alternative roads, it is possible to measure the total increased distances, spend times and $\mathrm{CO}_{2}$ emissions caused by all traffics on that day. In addition, the type of impacted vehicle (like freight car, electric car) should be taken into account. The above factors directly affect the total distances, travel times, and $\mathrm{CO}_{2}$ emissions. Furthermore, the multidimensional effects of flooding make the indicators' measurement more complex. For example, the increased use of alternative routes can change traffic situation in these roads, such as causing congestions that result in more increased travel times.

Moreover, the parameters of these three indicators are not certainly in a negative correlation with resilience value. When the complete Nantes territory is flooded, urban traffics could largely decrease due to road ruptures. In this situation, the increased distances and travel times on alternative roads mean, on the contrary, that the urban road network preserve still its performance and that people's mobility is not seriously blocked. This would mean that a lower parameter of the three selected indicators indices a worse urban resilience. These three indicators should therefore correspond to different criteria in different situations.
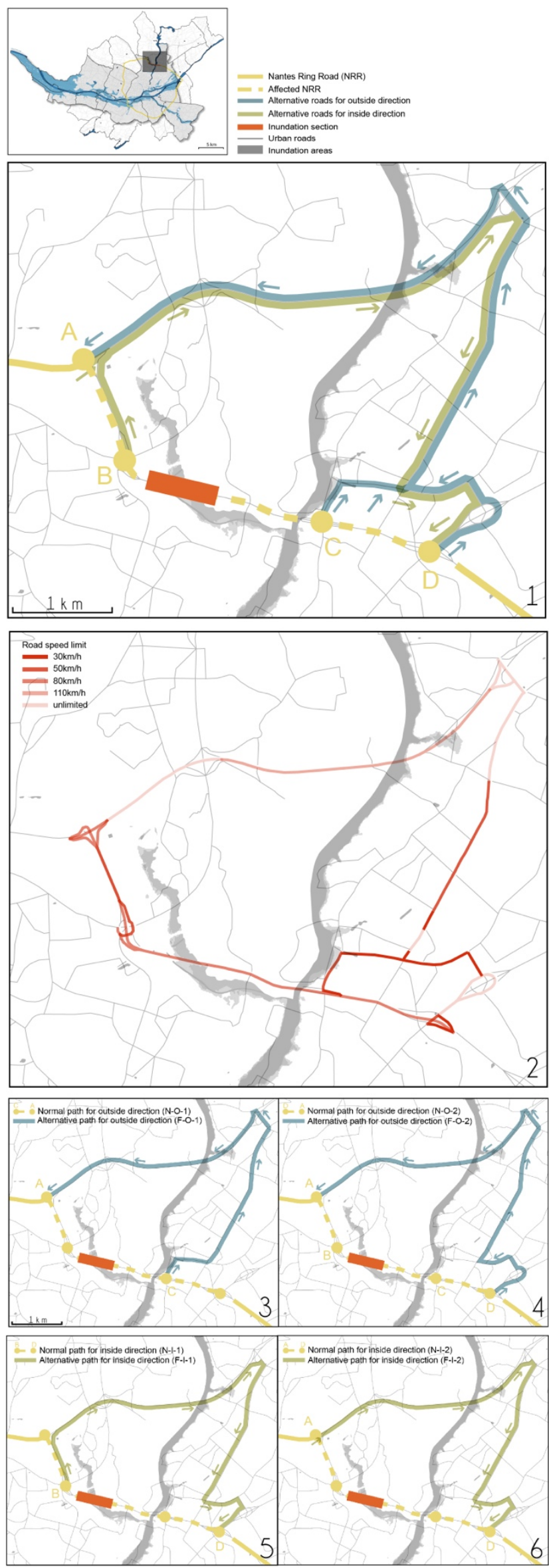

Figure 8. Suggested alternative routes in flooding events of the East NRR, Figure design inspired by DIRO (2015) and Open Data Nantes, Edited by the authors. 
Nevertheless, these three indicators are complementary to those usually used on RIs and which not concern the indirect consequences on urban systems. They provide the aspects on an ecological issue not immediately taken into account. Moreover, they allow us think about the consequences on other related urban social-economic system in the future. For example, longer journeys on less safe roads can also bring the insecurity of road users. Additionally, according to Cordier (2019), the average cost of individual French vehicle is 33.5 cents (Euro) per $\mathrm{km}$ (ignoring tolls and parking, which are linked to particular routes, motorways, tunnels, certain urban routes, etc.). Based on this data, we could calculate the increased economic cost of on each original and alternative routes (see Table 6).

\section{Conclusion}

Flood risks poses significant challenges to urban road infrastructures stakeholders around the world. Furthermore, infrastructure resilience assessment has been playing an indispensable role in urban flood management in current trend. Many French institutions involved in flood management discuss relevant assessment indicators in their documents. We divide these indicators as two types: practical indicators, used on practical urban project or management; and operational indicators, suggested in guides, plans, strategies, etc., which could serve as practical indicator. It is crucial to understand which practical indicators are used to French local road infrastructures, which operational indicators could be used and how to identify useful operational indicators.

After discussing the relation between "hazard" and "system" in resilience's definition, this paper identifies two assessed objectives of assessment indicators: the abilities of "system" reacting to "hazard"; and the consequences caused by "hazard" on "system". In addition, considering the continuous effects of flooding, two affected systems could be recognized in our study: road infrastructures and urban system. This would guide us to identify involved actors, investigate their published documents, and analyse the relevant indicators. It also helps us categorizing and comparing the practical indicators used in case study, NRR network, and the selection operational indicators. As a result, three operational indicators, worth studying, are highlighted: increased distances, increased times spend on the road, increased local pollution. The application of selected operational indicators on case study are based on GIS system and Nantes local resources, such as the alternative routes with flooding events, road speed limits. Finally, we find that the sections affected by floods in NRR have different resilience.

However, this research has some limits. Firstly, to find out the indicators concerning the abilities and the consequences of urban system, we may need to investigate the involved actors in "urban system" (political, socioeconomic, ecologic, etc.) and their documents. The indicators in these documents, both related to flooding and dysfunction of road infrastructure, deserve further development. Secondly, in case study discussion, we could further and clarify indicators' application approach with multi-disciplinary resources.

Although a number of challenges remain to complete indicators and local resources, this work provides an effective approach to identify French practical and operation indicators of road infrastructures resilience to flood risks and demonstrate how useful operational indicators can be applied to case study.

\section{Acknowledgements}

This paper shows a result of the RESIIST project (https://research gi.minesalbi.fr/display/resiist/RESIIST+Home [in French]) that is funded jointly by the French National Research Agency (ANR) and the General Secretary of Defense and National Security (SGDSN). The authors acknowledge these organizations for their support that helped improve the paper.

\section{References}

1. Cordier B. (2019). Le cout réel de la voiture en 2018. $11 p$.

2. Centre d'études et d'expertise sur les risques, l'environnement, la mobilité et l'aménagement (Cerema). (2015). Rapport d'étape, Plan National d'Adaptation au Changement Climatique (PNACC), volet infrastructures et systèmes de transport, volet infrastructures et systèmes de transport, action 3, Analyse des risques liés aux événements climatiques extrêmes sur les infrastructures, systèmes et services de transport - Recueil de concepts.

3. Centre d'études et d'expertise sur les risques, l'environnement, la mobilité et l'aménagement (Cerema). (2016). Référentiel national de vulnérabilité aux inondations.

4. Centre Européen de Prévention de Risque d'Inondation (CEPRI). (2016). Le territoire et ses réseaux techniques face au risque d'inondation.

5. Ministère de la Transition Écologique, Commissariat général au développement durable (CGDD). (2017). Indisponibilité d'une infrastructure de transport. Mesurer et réduire les coûts. $61 p$.

6. Commissariat général au développement durable (CGDD). (2018). Analyse multicritères des projets de prévention des inondations, Guide méthodologique.

7. Dantec G. \& Pipien G. (2019). Guide méthodologique "après inondation ": organisation de la collecte des données issues des REX inundation. Conseil général de l'environnement et du développement durable (CGEDD) and Centre d'études et d'expertise sur les risques, l'environnement, la mobilité et l'aménagement (Cerema), $122 p$.

8. Direction régionale de l'Environnement, de l'Aménagement et du logement (DREAL Centre), Agence de bassin Loire-Bretagn. (2011). Évaluation préliminaire du risque d'inondation sur le district Loire-Bretagne. Livre 1 Synthèse sur le basin. Direction régionale de l'environnement, de 
l'aménagement et du logement Centre - Val de Loire (DREAL Centre - Val de Loire), 98 p.

9. Direction régionale de l'Environnement, de l'Aménagement et du logement (DREAL), Pays de la Loire. (2014). Dossier de concentration, Aménagement du périphérique nord de Nantes.

10. Direction régionale de l'Environnement, de l'Aménagement et du logement (DREAL), Pays de la Loire. (2016). Le périphérique de Nantes, enjeux \& projets, dossier de presse.

11. Direction Interdépartementale des Routes Ouest (DIRO). (2015). Procédure inondation du périphérique Est de Nantes. Rapport interne, 6p.

12. Etablissement Public Loire. (2006). Etude préalable à la réduction de la vulnérabilité des réseaux liés aux inondation en Loire Moyenne, Résultats, Bilan et Perspectives.

13. Ganin, A. A., Kitsak, M., Marchese, D., Keisler, J. M., Seager, T., \& Linkov, I. (2017). Resilience and efficiency in transportation networks. Science Advances, 3(12), 1-9. https://doi.org/10.1126/sciadv.1701079

14. Goltermann, D., Ujeyl, G., \& Pasche, E. (2009). Making Coastal Cities Flood Resilient in the Era of Climate Change. 4th International Symposium on Flood Defence: Managing Flood Risk, Reliability and Vulnerability, 2000, 148-1-148-11.

15. Gonzva, M., Barroca, B., \& Serre, D. (2017). Résilience des systèmes urbains: proposition d'un cadre méthodologique pour répondre aux besoins des exploitants. Colloque international «Penser et faire la résilience. Risques et territoires $»$.

16. Holling, C. S. (1973). Resilience and stability of ecological systems. Annual review of ecology and systematics, 4(1), 1-23.

17. Larrue, C., Bruzzone, S., Lévy, L., Gralepois, M., Schellenberger, T., Trémorin, J. B., Fournier, M., Manson, C., \& Thuilier, T. (2016). Analysing and evaluating flood risk governance in France. From state policy to local strategies.

18. L'environnment en France (2019). Rapport sur l'état de l'environnement-Les émissions de gaz à effet de serre des transports, Fiches thématiques. Consultant in: https://ree.developpementdurable.gouv.fr/themes/defis-

environnementaux/changement-

climatique/emissions-de-gaz-a-effet-de-

serre/article/les-emissions-de-gaz-a-effet-de-serredes-transports

19. European exchange circle on flood mapping (EXCIMAP). (2007). Handbook on good practicals for flood mapping in Europe.

20. Nantes Métropole. (2017). Stratégie locale de Gestion des Risques d'Inondation (SLGRI) du Territoire à Risque Important (TRI) d'inondation de Nantes

21. Pregnolato, M., Ford, A., Glenis, V., Wilkinson, S., \& Dawson, R. (2017). Impact of Climate Change on Disruption to Urban Transport Networks from Pluvial Flooding. Journal of Infrastructure Systems, 23(4), 04017015. https://doi.org/10.1061/(asce)is.1943$555 \times .0000372$
22. Priest, S. J., Suykens, C., van Rijswick, H. F. M. W., Schellenberger, T., Goytia, S., Kundzewicz, Z. W., van Doorn-Hoekveld, W. J., Beyers, J. C., \& Homewood, S. (2016). The European union approach to flood risk management and improving societal resilience: Lessons from the implementation of the Floods Directive in six European countries. Ecology and Society, 21(4). https://doi.org/10.5751/ES-08913210450

23. United Nations International Strategy for Disaster Reduction (UNISDR). (2009). Terminology on disaster risk reduction. Geneva, Switzerland.

24. Yang, Z., Bony-Dandrieux, A., Barroca, B., \& Dolidon, H. (2020) Assessing urban transport network resilience: a review on current approaches, International Conference on Transport and Smart Cities. ICoTSC 2020 - 2020 International Conference on Transport and Smart Cities, Oct 2020, Madrid, Spain. 